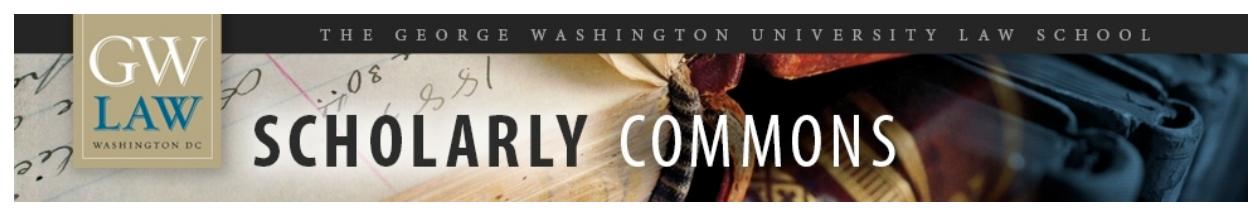

\title{
Duty to Rescue? Exploring Legal Analysis Through the Lens of Photojournalists' Storytelling Dilemmas
}

Iselin Magdalene Gambert

George Washington University Law School

Follow this and additional works at: https://scholarship.law.gwu.edu/faculty_publications

Part of the Law Commons

\section{Recommended Citation}

Iselin M. Gambert (2014) Duty to rescue? Exploring legal analysis through the lens of photojournalists' storytelling dilemmas, The Law Teacher, 48:2, 140-153, DOI: 10.1080/03069400.2014.914688

This Article is brought to you for free and open access by the Faculty Scholarship at Scholarly Commons. It has been accepted for inclusion in GW Law Faculty Publications \& Other Works by an authorized administrator of Scholarly Commons. For more information, please contact spagel@law.gwu.edu. 
Note: This is an Accepted Manuscript of an article published by Taylor \& Francis Group in The Law Teacher on 22 May, 2014, available online:

http://www.tandfonline.com/action/showCitFormats?doi=10.1080/03069400.2014.914688

\title{
Duty to rescue? Exploring legal analysis through the lens of photojournalists' storytelling dilemmas
}

\author{
Iselin M. Gambert \\ Associate Professor of Legal Research and Writing \\ The George Washington University Law School \\ 2000 H Street NW, Washington, DC, 20052 USA
}

\begin{abstract}
In depicting scenes of tragedy, what happens when photojournalists become the story? Do photojournalists have a duty to rescue those they photograph? Should they? This article will use a series of iconic images - and the stories of the photojournalists behind the camera - to illustrate how exploring these questions can be a provocative vehicle through which to engage new law students in legal writing and analysis. The article focuses on an exercise that centers around a fictional "Duty to Rescue" statute modeled after European statutes of the same kind. The exercise is anchored by four images - three still photographs and one image that is part of a short documentary film - of people in tragic and near-death situations. The article explores ways to use the stories behind these images to engage law students in the question of whether the photojournalists who took the images had violated the fictional Duty to Rescue statute, and concludes with a discussion of ideas on how the basic exercise can be modified and/or expanded, including but not limited to raising issues of morality-based lawmaking, ethics, fairness, and differences in law across cultures.
\end{abstract}

Email: igambert@law.gwu.edu 


\section{Introduction: bringing legal stories to life in the first-year law school classroom}

In photojournalism, most of the prize-winning photographs are those where you are photographing someone else's tragedy in life. These photojournalists, like myself, benefitted from someone else's misfortune. ... In all of these other situations that I've been in around the world, I feel helpless as a person on the other side of the camera to do anything except record what's going on. And here's a situation where I could have caused a difference, a major difference, and I didn't. And that's why it's so disturbing. (Marcus Halevi) ${ }^{1}$

The transition from "regular person" to "law student" can be a rocky one indeed. Many of us who went through the transformation from layperson to lawyer may remember those dizzying first days - days filled with an overwhelming amount of reading from thick, cloth-bound casebooks whose contents often felt stale, murky, and frozen in some distant time where disagreements over dead foxes reigned supreme. ${ }^{2}$

The famous fox case Pierson $v$ Post was very much on my mind the day I received my job offer to teach legal writing (essentially a course in rhetoric and analysis) at The George

\footnotetext{
${ }^{1}$ See Act III: Still Life, from the "My Way" episode, This American Life Season 1. This episode is available for download on iTunes. At the time this article was written, it was also available online at http://seftel.com/thisamerican-life/ (accessed 7 January 2014).

${ }^{2}$ In her article "It's Not about the Fox: The Untold History of Pierson v. Post", Bethany Berger discusses the overwhelming popularity of the famous fox case Pierson $v$ Post, 3 Caines 175 (NY 1805), in first-year property courses in the United States, and the effect that reading iconic cases such as Pierson has on new law students. "Imagine you are a first year law student eager for initiation to the mystery and power, the nobility and heartbreak, of the law" Berger writes. B. Berger, "It's Not about the Fox: The Untold History of Pierson v. Post" (2006) 55(6) Duke Law Journal 1089, at p. 1090. [AQ1] "You open your casebook to read your first assignment in property law and find ... a centuries old dispute about a fox. ... You sadly go to class, realizing that law school won't be quite as you imagined it. Two hundred years after Pierson $v$ Post was decided, the case continues to horrify successive generations of law students with the thought that success in law school means understanding debates among nineteenth century judges regarding the relevance of sixth century treatises about the ownership of a dead fox." Ibid., at pp. $1090-1091$.

This article is written through the lens of the US common law legal system and US Juris Doctor legal educational model. Specifically, unlike many countries where students enter law school as undergraduates, law students in the US are graduate students who have completed four years of undergraduate study and who are now enrolled in a three-year Juris Doctor program. It is difficult to speculate how the class discussions referenced in this article may be different if held in the context of a different legal system and/or educational model, but because so many of the core principles of legal analysis - identifying legally significant facts, recognizing ambiguities in statutory language, and developing an organized approach through which to analyze a legal problem - are constant the world over, law professors from any country should be able to find value in the exercise described here. That said, professors in civil law countries and/or in countries where law students are undergraduates may wish to modify the exercise and discussion topics to better serve the needs of their students.

Law students in other countries undoubtedly have their own versions of iconic cases like Pierson $v$ Post; in the United Kingdom the well-known "snail in the ginger beer bottle" case of Donoghue v Stevenson [1932] AC 562, House of Lords, likely plays a similar role in the lives of many first-year law students.
} 
Washington University Law School. In the months and years after those overwhelming first days of law school, I came to appreciate Pierson and all the other cases I was assigned to read for what they are: legal stories, often involving fascinating and unlikely plot twists and always starring real-life people, places, and things that had a real stake in the story's conclusion. The problem with iconic but ancient cases like Pierson is that something about them - the way they were written, the topics they are about - makes them feel to a twenty-first-century law student as though they have lost their relevance. And without relevance, there is a real risk that the stories these cases tell will remain lifeless words on a page, eluding the appreciation that the students' professors feel they deserve. Mindful of this, I asked myself this question: what could I offer my students in those first few days of law school that may bring to life the "mystery and power, the nobility and heartbreak" of the law more effectively than a centuries-dead fox? ${ }^{3}$

I decided that perhaps the best way to introduce my students to the magic and power of legal storytelling and analysis was through the lens of other non-fiction stories, ideally ones whose poignancy and urgency brought with them a greater sense of relevance than the legal stories typically told to new law students. I turned to the popular non-fiction storytelling show This American Life ${ }^{4}$ for inspiration, reasoning that developing an exercise grounded in a provocative, contemporary, non-legal story would be an effective way to ease students through the transition from laypeople to legal thinkers. I found a six-minute video clip from the show's first television season that I knew instantly would be the perfect centerpiece for my first law school class. The clip, which tells the story of a photojournalist grappling with a life-and-death decision while on assignment, raises a series of provocative questions that introduce new law

\footnotetext{
${ }^{3}$ Berger, supra n. 2, at p. 1090.

${ }^{4}$ This American Life is a non-fiction storytelling program most commonly known for its weekly radio show, produced by WBEZ Chicago. See www.thisamericanlife.org (accessed 22 March 2014). Between 2007 and 2008 , the program also aired two seasons of television shows on the cable network Showtime. The radio and television shows can be streamed online and purchased through iTunes.
} 
students to a wide range of lawyering skills: In depicting scenes of tragedy, what happens when photojournalists become the story? Do photojournalists have a duty to rescue the people they photograph? Should they?

\section{Capturing the photojournalist's dilemma}

Every photographer who has been involved in these stories has been affected. You become changed forever. Nobody does this kind of work to make themselves feel good. It is very hard to continue. (James Nachtwey, American photojournalist who worked with Kevin Carter $)^{5}$

Behind every image that graces our eyes is a never-to-be-seen scene unfolding behind the lens. Photojournalists by definition photograph newsworthy events, and those events often include people in danger or despair. What is the proper role of a photojournalist who encounters a newsworthy situation of someone in distress? This is a question with no easy answer, and whose ethical answer may differ from its legal one. Reasonable minds may differ, and lawmakers in varying jurisdictions certainly do. ${ }^{6}$

The "photojournalist's dilemma"7 lends itself well to teaching new law students about legal storytelling and analysis because of the wide expanse of grey area it encompasses and near absence of black or white. The idea that what's fair or "right" may not be legal is a tricky one to embrace for idealistic lawyers-in-training. That the law may be one thing in one place and the polar opposite somewhere else is another challenge worth having students grapple with.

Beyond providing a provocative space for students to struggle with notions of ethics, justice, fairness, and morality, the "photojournalist's dilemma" also provides new law students

\footnotetext{
${ }^{5}$ S. MacLeod, “The Life and Death of Kevin Carter", TIME Magazine (24 June 2001), available at http://content.time.com/time/magazine/article/0,9171,165071,00.html (accessed 4 January 2014).

${ }^{6}$ See infra n. 50.

${ }^{7}$ Scott MacLeod used this term in his TIME Magazine article "The Life and Death of Kevin Carter". See supra n. 5.
} 
with an opportunity to learn about and engage in legal analysis in an almost intuitive way, without all the jargon, acronyms, and formalities that often accompany the process.

The "photojournalist's dilemma" enters my classroom on the first day of law school with little context or explanation. ${ }^{8}$ I introduce it, after welcoming the students and saying a few things about myself, by posing the following two questions: Do photojournalists have a duty to rescue the people they photograph? Should they?

Depending on how much time you have and your pedagogical goals, you may treat these as rhetorical questions, but I like to pause and wait for a few people to share their thoughts. You can call on people, take responses from volunteers, or have students discuss in pairs or groups. You're likely to find that these are questions your students have never considered before, but which they have strong opinions about once they start thinking about them.

After posing these questions and engaging in a short discussion - ideally one where views on both sides of the issue are raised - I proceed to show the students a series of photographs.

\section{Napalm Girl}

The first photograph I show the students is arguably one of the most iconic images of war; it is known by most people as Napalm Girl. ${ }^{9}$ The image, taken by photojournalist Nick Ut in Vietnam during the war in 1972, depicts a horrific scene of children, soldiers, and journalists running away from a large explosion. One of the children is naked, her arms stretched out to the sides and her clothes burned and melted off from the napalm.

\footnotetext{
${ }^{8} \mathrm{I}$ have found that diving right in without providing context is a great way to keep the students on their toes and to disarm them of any preconceived notions of what a legal writing class, or law school class, will be like.

${ }^{9}$ Napalm Girl can be viewed online here: http://tinyurl.com/kdoan9v. In the event that this URL becomes inactive in the future, the full URL is as follows: http://www.apimages.com/metadata/Index/Watchf-AP-I-VNM-APHS021000Vietnam-Napalm-1972/f3250f1c35064724a60969b0f411b7f3/12/1. For a short history of the image, see "“Napalm Girl': An Iconic Image of War Turns 40”, at http:/www.npr.org/2012/06/03/154234617/napalm-girl-an-iconicimage-of-war-turns-40 (accessed 6 January 2014).
} 
While a great many people are familiar with this photo, ${ }^{10}$ which won the Pulitzer Prize for Spot News Photography in $1973,{ }^{11}$ far fewer know anything about what happened behind the lens. Do you think Mr Ut had a duty to try to help these children? I ask. If not, should he have had one?

My students are often divided on these questions. Often at least one student will point out that because this image was taken in a war zone in a foreign country, no duty to aid the children likely existed. Sometimes no one brings this up, however, and in those cases I typically ask my students whether it likely matters that the photo was taken during a war in a distant land. This question is likely to generate some conversation about the ability of law from one country to reach the soil of another, and about the unique legal landscape that a war zone presents. These topics, while fascinating, are only tangentially related to the core exercise, so the amount of time you dedicate to this discussion is up to you. I like to raise the issues but don't linger long enough to provide any specific answers.

What if this same image had been captured on US soil, not during wartime but during some other disaster-perhaps a power plant explosion or wildfire? In other words, what if we could assume that the laws of the US governed this situation? This is when things get murkier.

After a bit of discussion but without waiting for students to come to a consensus on these last questions, I ask them if they know what, if anything, Nick Ut actually did after taking this photograph. So far none of my students has been familiar with the story behind the lens.

\footnotetext{
10 "Whatever your age, you've probably seen this photo," remarked the journalist who wrote "'Napalm Girl': An Iconic Image of War Turns 40". See supra n. 9. Despite its status as one of the most iconic war images of the twentieth century, you may wish to ask your students if they are familiar with this image; each year I have a number of students who have never seen it before. The exercise does not depend on your students having seen this image before, but if they are not familiar with it you will find it useful to give them a bit of background on the image - the year it was taken, and the fact that it was taken by a photojournalist during a napalm attack in Vietnam during the war - to put it into context for them.

${ }^{11}$ See http://www.pulitzer.org/bycat/Spot-News-Photography (accessed 6 January 2014). Nick Ut is referred to by his Vietnamese name, Huynh Cong Ut, and the image is referred to by the name "The Terror of War".
} 
“[W]hen she passed my camera, I saw her body burned so badly, I said, 'Oh my God, I don't want no more picture,"' said Ut in a 2012 interview marking the 40th anniversary of the image. ${ }^{12}$ "That's when I stopped taking pictures of her. ... I then put my four cameras down on Highway One, and began helping her."13

The girl, whose name is Kim Phuc, "was screaming and crying, 'I'm dying, I'm dying, I'm dying ... I need some water. Bring water." ${ }^{14}$ Says Ut, "I run out and put water on her body. I want to help her. I say, 'No more pictures. I want to help [her] right away.",15

Ut piled Phuc and all the other children into his van and headed to the hospital. ${ }^{16}$ The hospital "was packed, with bodies, dying people, and the wounded everywhere". ${ }^{17}$ Ut asked the doctors and nurses to help the children, but was told by a nurse who had seen their condition, "Normal medicine cannot help. We cannot do anything." ${ }^{, 18}$ At that point, Ut showed the nurse his media pass and said, "If these kids die, you'll be in trouble tomorrow." ${ }^{19}$ According to Ut, "Once they knew I was media, they carried Kim inside right away." 20

Kim Phuc survived the bombing. Ut stayed in touch with her, visiting her in the hospital and checking in on her for years afterward. ${ }^{21}$ They're in touch even today - Phuc lives in Canada and speaks to Ut once a week. She calls him "Uncle Nick". ${ }^{22}$

\footnotetext{
${ }^{12}$ See "Documentary Video: The Napalm Girl" by Content Media Group, available at http://www.youtube.com/watch?v=Pa9auMart0E (accessed 6 January 2014).

${ }^{13}$ See "Interview with Nick Ut, the Photojournalist Who Shot the Iconic 'Napalm Girl' Photo", available at http://petapixel.com/2012/09/19/interview-with-nick-ut-the-photojournalist-who-shot-the-iconic-photo-napalm-girl/ (accessed 12 January 2014).

${ }^{14}$ Supra n. 12. [AQ2]

${ }^{15}$ Supra n. 12.

${ }^{16}$ Supra n. 13.

${ }^{17}$ Supra n. 13.

${ }^{18}$ Supra n. 13.

${ }^{19}$ Supra n. 13.

${ }^{20}$ Supra n. 13.

${ }^{21}$ Supra n. 13.

${ }^{22}$ Supra n. 13.
} 


\section{Vulture}

Not every photojournalist's story has such a happy ending.

The next photo I show my students is another iconic image of a child in distress. Known simply as Vulture, the image portrays an emaciated child, naked and huddled over in exhaustion, hunger, or both. A large brown vulture sits a few meters behind the child, waiting. I provide a bit of context about the photo - the year the photo was taken, the country it was taken in, and the name of the photographer - so that students who aren't already familiar with the image are not at a disadvantage. Do you think the photographer here had a duty to try to help this child? I ask. If not, should he have had one? I'm careful to point out that this image was taken not in an active war zone, but rather at the site of a humanitarian feeding center. ${ }^{23}$

Again, though my students are often divided on this question, most of them usually conclude that because this image was taken in a foreign country, no duty likely existed - at least none governed by laws of the United States. They remain divided when I ask whether their answer would be different if this image was taken on US soil.

As with Napalm Girl, virtually none of my students has been familiar with the story behind Vulture's lens.

Kevin Carter, a South African photojournalist in his early 30s, traveled to Sudan in 1993 to photograph the rebel movement in the famine-stricken village of Ayod. ${ }^{24}$ As soon as he stepped off the plane,

Carter began snapping photos of famine victims. Seeking relief from the sight of masses of people starving to death, he wandered into the open bush. He heard a soft, high-pitched whimpering and saw a tiny girl trying to make her way to the feeding center. As he crouched to photograph her, a vulture landed in view. Careful not to disturb the bird, he positioned himself for the best possible image. He would later say he waited about 20 minutes, hoping

\footnotetext{
${ }^{23}$ Vulture can be viewed online here: http://tinyurl.com/mdsvxs8. In the event that this URL becomes inactive in the future, the full URL is as follows: http://www.corbisimages.com/stock-photo/rights-managed/0000295711001/famine-in-sudan. See also http://www.pulitzer.org/bycat/Feature-Photography (accessed 12 January 2014).

${ }^{24}$ Supra n. 5.
} 
the vulture would spread its wings. It did not, and after he took his photographs, he chased the bird away and watched as the little girl resumed her struggle. Afterward he sat under a tree, lit a cigarette, talked to God and cried. ${ }^{25}$

The New York Times bought the iconic image and made it famous; it won the Pulitzer Prize for Feature Photography in $1994 .{ }^{26}$ Carter's reputation as a photojournalist soared, but he also faced extreme criticism for benefitting from the starving girl's image while doing nothing to help her. ${ }^{27}$ Some of Carter's friends wondered why he did nothing to try to help the girl, and the Florida-based St. Petersburg Times ran a story asserting that "[ $\mathrm{t}]$ he man adjusting his lens to take just the right frame of her suffering might just as well be a predator, another vulture on the scene". 28

Carter told a friend that he was "really, really sorry [he] didn't pick the child up". ${ }^{29}$ Carter struggled with the "photojournalist's dilemma" in other contexts as well. Describing his experience taking photos of a shoot-out, he said,

I had to think visually. I am zooming in on a tight shot of the dead guy and a splash of red. Going into his khaki uniform in a pool of blood in the sand. The dead man's face is slightly gray. You are making a visual here. But inside something is screaming, "My God." But it is time to work. Deal with the rest later. If you can't do it, get out of the game. ${ }^{30}$

Not long after winning the Pulitzer Prize - and less than two years after taking the Vulture image, Kevin Carter got out of the game forever, committing suicide at age 33. 'I'm really, really sorry", read his suicide note, a rambling message in which he admitted to being "haunted by the vivid memories of killings \& corpses \& anger \& pain ... of starving or wounded children, of

\footnotetext{
${ }^{25}$ Supra n. 5.

${ }^{26}$ Supra n. 23.

${ }^{27}$ It's unknown whether the girl made it to the feeding center she was headed toward; her fate beyond that day is unknown. See supra n. 5.

${ }^{28}$ Supra n. 5.

${ }^{29}$ See F.H. Cate, “Through a Glass Darkly” (1999) (citing P. Martin, “I'm Really, Really Sorry I Didn’t Pick the Child Up", Sunday Mail (London), 16 October 1994, at p. 40), available at http://www.lehigh.edu/ j10d/J24606/THROUGH\%20A\%20GLASS\%20DARKLY\%20(full\%20text).htm (accessed 13 January 2014).

${ }^{30}$ Supra n. 5.
} 
trigger-happy madmen, often police, of killer executioners". ${ }^{31}$ The letter concludes, "[t]he pain of life overrides the joy to the point that joy does not exist". 32

Carter's suicide resonated with Nick Ut. In a 2012 interview Ut reflected on Carter's

Vulture and his own Napalm Girl and on their respective actions off camera:

A lot of people learn from my picture. People who want to help. When you see people get shot, or injured people, or people who need help, you don't just watch and let people die. Remember Kevin Carter and his picture of the bird waiting to eat the little child. That's why he killed himself. For the napalmed girl, if I didn't help her and she died, I would have killed myself too. ${ }^{33}$

\section{Untitled (subway image)}

The third photograph I show my students is the most recent - an image taken in 2012 by

freelance photographer R. Umar Abassi in a New York City subway tunnel. The image depicts a man who has fallen on to the subway tracks; he is facing an oncoming train and clinging tightly to the station platform.

Moments after this image was taken, the man was struck by the train and killed. The image appeared on the front page of the New York Post the following day. ${ }^{34}$

The publication of the image was criticized widely for being insensitive, but the story behind the lens became an even more controversial one. As NBC's Today Show weatherman Al Roker asked, “Somebody’s taking that picture. Why aren’t they helping this guy up?’35

\footnotetext{
${ }^{31}$ Supra n. 5.

${ }^{32}$ Supra n. 5.

${ }^{33}$ Supra n. 13. See also "AP 'Napalm Girl' Photo from Vietnam War Turns 40”, available at http://www.ap.org/Content/AP-in-the-News/2012/AP-napalm-girl-photo-from-Vietnam-War-turns-40 (accessed 12 January 2014).

${ }^{34}$ R. Umar Abassi's subway image can be viewed online here: http://tinyurl.com/k7wm2ey. In the event that this URL becomes inactive in the future, the full URL is as follows: http://thenypost.files.wordpress.com/2013/09/201212-04-front.jpg. See also D. Macleod, “A Picture of Controversy”, New York Post (5 December 2012), available at http://nypost.com/2012/12/05/a-picture-of-controversy/ (accessed 13 January 2014). Macleod's article, which discussed the controversy surrounding the Post's decision to publish Abassi's image on its front page, mentions that an anonymous Gawker commenter "compared it to an iconic 1993 photograph of a starving girl in Africa with a vulture ominously standing behind her. It 'drew the same kind of criticism (and still won a Pulitzer), as might any photo of critical situations,' wrote the commentator." Ibid.
} 
Abassi claimed that he was "being unfairly beaten up in the press", and emphasized that "[n]obody helped" and that "[p]eople started running away" when they saw the man in the tracks. ${ }^{36}$ Abassi claimed that he wasn't even trying to photograph the man, but rather his aim was to send a signal of flashes to the train conductor in an effort to get the train to stop. "If I had reached him in time, I would have pulled him up," he said. "38 "Every time I close my eyes, I see the image of death," concluded Abassi. "I9 "I don't care about a photograph."40

\section{Untitled (wave image)}

The final image I show my students isn't a photograph at all, but rather a short video clip from the non-fiction storytelling show This American Life. ${ }^{41}$ The video tells the story of photojournalist Marcus Halevi and a woman he encountered while covering a storm on assignment for the Lawrence Eagle-Tribune in 1991. I give my students no introduction other than encouraging them to listen closely and to feel free to take notes.

In the video, Halevi describes how he was taking pictures of the storm on Plum Island, and how "[t]here was this one figure standing by the ocean, looking out. She was drinking a beer ... and having a smoke[.]"42 He began photographing her, remembering how "a split second after [one of his photos] was taken, a wave came in, hit the embankment below her feet, knocked the sand out and she went sliding into the water". ${ }^{43}$

\footnotetext{
${ }^{35}$ See M. Wilson and D. Krieger, “After Fatal Subway Shove, Asking: Were There No Heroes?”, The New York Times (4 December 2012), available at http://www.nytimes.com/2012/12/05/nyregion/suspect-in-fatal-subway-pushis-in-custody.html?_r=0 (accessed 12 January 2012).

${ }^{36}$ Supra n. 35.

${ }^{37}$ Supra n. 35.

38 Supra n. 35.

39 Supra n. 35.

${ }^{40}$ Supra n. 35. See also J. Palazzalo, "Duty to Rescue”, The Wall Street Journal Law Blog (4 December 2012), available at http://blogs.wsj.com/law/2012/12/04/the-duty-to-rescue/ (accessed 8 January 2014).

${ }^{41}$ Supra n. 1. Marcus Halevi's film can be viewed online here: http://seftel.com/this-american-life/.

${ }^{42}$ Supra n. 1.

${ }^{43}$ Supra n. 1.
} 
"I was probably at least 50 feet away from her, shooting with a telephoto lens," explained Halevi." "She was in the water, either in shock or just drunk, or whatever. And I thought about, okay, am I gonna try to make a rescue? I've already got the shot I need. I turned around - within 100 feet of me, there was a lifeguard. So, uh, I continued to photograph the sequence.”45

Halevi describes how a man who was with the lifeguard reached the woman first and reached out to her to "grab her hand and pull her to safety, but - at the last second something stopped him". 46

Says Halevi, "The wave to me looked like it was about 20 feet high. Within seconds after this photograph was taken, she was consumed by the wave. I realized that she was, she was gone." 47

Like Vulture and the image taken in the New York City subway tunnel, Halevi's images from that day "received quite a bit of attention, and a lot of criticism came in to the Lawrence Eagle-Tribune about their photographer who watched someone drown in the ocean while he just continued to take pictures". ${ }^{48}$

Halevi - who today focuses on "happy situations, never life-threatening situations" in his work, is haunted by his actions that day. "One of the things that I have real problems with and I haven't really resolved," he explained, is that "perhaps, if I hadn't taken the five or ten seconds, if I hadn't responded to my instincts to first take the shot, perhaps that time would have [made] the difference between life and death."50

\footnotetext{
${ }^{44}$ Supra n. 1.

${ }^{45}$ Supra n. 1.

${ }^{46}$ Supra n. 1.

${ }^{47}$ Supra n. 1.

${ }^{48}$ Supra n. 1.

${ }^{49}$ Supra n. 1.

${ }^{50}$ J. Kredens, “Of Life and Death: Photos Capture Woman's Last Moments”, in Indiana University Journalism Ethics Cases Online, available at http://journalism.indiana.edu/resources/ethics/controversial-photos/of-life-anddeath/ (accessed 8 January 2014).
} 


\section{From photographer's dilemma to lawyer's analysis}

The classroom is usually silent for several moments when I turn the lights back on after Marcus

Halevi's film concludes. I allow that silence to sink in before proceeding.

Until this moment I've done nothing to formally introduce the legal concept of "duty to rescue" other than ask the broad questions, Do photojournalists have a duty to rescue the people they photograph? and Should they? I haven't explained that "duty to rescue" is in fact a real thing, the law of the land in much of the world, though rejected by Anglo-American common law and only recognized by statute in some limited capacity in fewer than a dozen states in the US. ${ }^{51}$ I intentionally keep all of this background information from the students at this stage because I want them to move into the next portion of the exercise armed only with their own ideas of what's right and wrong and what should or should not be the law; I don't want their own opinions influenced by reality - not yet, anyway.

"You are all law clerks," I tell the students as I distribute handouts containing the next component of the exercise. The handout reads as follows:

\footnotetext{
${ }^{51}$ For a detailed history of the "duty to rescue" doctrine in the United States and elsewhere, see C. White, "No Good Deed Goes Unpunished: The Case for Reform of the Rescue Doctrine" (2002) 97 Northwestern University Law Review 507. As White explains, "[t]hroughout its history, American law has viewed rescuers in a peculiar and unfavorable light. Under traditional common-law rules, individuals have no duty to come to the aid of others trapped in dangerous situations. Those who attempt to render help can face severe legal and financial consequences." Ibid., at p. 507.

White further explains that the Anglo-American approach "is in stark contrast with that adopted in most European civil law jurisdictions", clarifying that duty to rescue laws "are longstanding in many European nations. Portugal adopted the first such law in 1867. The Netherlands, Finland, and Italy all enacted similar legislation in the nineteenth century, and most of the other countries of continental Europe did so in the early to middle twentieth century." Ibid., at p. 510. In advocating a reform of the rescue doctrine in the United States, White quotes a commentator who wrote that "although the duty to assist an injured or endangered person is commonplace throughout the world, our law continues to rely solely on man's unselfish spirit."' Ibid., at p. 510 (quoting J. Silver, "The Duty to Rescue: A Reexamination and Proposal" (1985) 26 William \& Mary Law Review 423 (arguing that a duty to rescue rule should be recognized in the United States)).

Despite the rejection of a "duty to rescue" doctrine by US common law, a number of states have enacted legislation to require rescue in some limited contexts. Eugene Volokh provides an overview of these states and their laws on his blog, The Volokh Conspiracy. See E. Volokh, "Duty to Rescue/Report Statutes" (3 November 2009) available at http://www.volokh.com/2009/11/03/duty-to-rescuereport-statutes/ (accessed 11 January 2014).
} 
You are a law clerk at the Washingtonia County Court. Defendant Marcus Halevi has been accused of violating W.C. $\S 42.3$ and is appearing in court today. Your judge asked you to brief her on whether Halevi violated the following statute:

\section{Washingtonia Code $§ 42.3$ Duty to rescue.}

Any person above legal age, who encounters another human being within a reasonably close range whose life, health, or safety is at risk, must take all practicable steps to rescue the distressed individual. A person's duty to rescue is waived when (1) an emergency worker (police, firefighters, emergency medical technicians, etc.) is within 50 feet of the person in distress, or (2) when providing assistance will clearly endanger the life of the rescuer. The aforementioned exceptions do not apply to persons who are acting within the scope of their employment when they encounter the distressed individual. ${ }^{52}$

At this point not only have I not told the students anything about the duty to rescue doctrine, but I have also told them exactly nothing about how to conduct a legal analysis. I haven't mentioned IRAC or CREAC or TREAT (the acronym used at the George Washington University), ${ }^{53}$ and I haven't said anything about statutory interpretation, case law, holdings, analogies, distinctions, or the like. I don't tell the students whether the statute is civil or criminal in nature. ${ }^{54}$ I break the students up into groups of three and tell them they have about 10 minutes to reach a conclusion. ${ }^{55}$

What follows is fascinating: virtually all of the students seem to instinctively understand what to do with the statute. They intuitively know that they need to look through their notes and

\footnotetext{
${ }^{52}$ Because there is no widespread duty to rescue law in the United States, I developed this fictional statute for purposes of this exercise. While I intentionally crafted the statutory language to work well with the Marcus Halevi facts and to contain sufficient ambiguity to generate vibrant class discussion, the essence of the statute was inspired by language from real duty to rescue statutes, many of them covered in Eugene Volokh's 2009 overview on The Volokh Conspiracy blog. See supra n. 51.

${ }^{53}$ IRAC, CREAC, and TREAT are three common acronyms commonly used in the US legal writing classroom to teach students the steps involved in conducting a legal analysis. IRAC stands for Issue, Rule, Application, Conclusion, while CREAC replaces "Issue" with a Conclusion up front and isolates out a distinct Explanation section to ensure that writers adequately explain the rule and how it works. TREAT is another variation on the same theme, swapping out Conclusions for Thesis statements.

${ }^{54}$ This is one of the questions I ask during the discussion after students have had the chance to work through the statute. Few students consider this question in the moment, but when I pose the question many of them understand that it's one of the many critical things to think about when conducting a legal analysis.

${ }^{55}$ This exercise would also work well if you told your students that they had to argue for a particular outcome. I like leaving it up to them because I think it forces them to grapple even more with the ambiguity of the statute, but there would be a number pedagogical benefits to the other approach.
} 
identify the legally significant facts from the video. "Didn't he say he was at least 50 feet away?" someone will typically ask out loud.

There has been more unevenness in students' innate ability to understand that many of the terms in the statute are ambiguous. Many of them intuit that the meaning of terms like "reasonably close range", “all practicable steps", “emergency worker”, "clearly endanger", "within the scope of their employment" and others are up for debate and interpretation; some students even know that ideally they would look to cases to see how these phrases were used and interpreted in other situations. Some students don't see the ambiguities as quickly and jump to assumptions about the meaning of those terms.

After about 10 minutes of deliberation I move the students into a class-wide discussion. I ask each group to explain its conclusion, with dissenting views welcome. The students are typically all over the map, with some groups feeling strongly that Halevi had violated the statute and others feeling that he hadn't, and still others deeply divided.

I then ask a series of questions designed to get the students thinking about the importance of identifying legally significant facts. Specifically, I ask whether the students' position would change if (1) Halevi was 10 feet away instead of at least 50; or (2) there was no lifeguard in sight; or (3) the woman screamed, "Help!" and looked in Halevi's direction; or (4) there was no sign that the woman had been drinking; or (5) Halevi was a world-class swimmer with deep sea diving experience; or (6) Halevi just happened to be taking a walk on the beach when he encountered the woman and was not there on assignment; or (7) the woman was a good friend of Halevi who he'd recently had a falling out with. ${ }^{56}$

\footnotetext{
${ }^{56}$ This is obviously a non-exhaustive list; any number of questions could be added to the list, and the amount of time you spend on discussion of each one is up to you.
} 
I also ask a series of questions designed to get students thinking about the importance of isolating ambiguous words and phrases in a statute. What is a "reasonably close range"? I ask them. Is 50 feet always reasonably close? Does context matter? What is a "practicable step"? Is a lifeguard definitely an "emergency worker"? What does "etc." mean in "police, firefighters, emergency medical technicians, etc. ”?

Asking these questions inevitably leads to a discussion about the role of case law in helping lawyers and judges interpret ambiguous statutes in a common law system. ${ }^{57}$ We also discuss the importance of knowing whether a statute is civil or criminal in nature, and how despite the fact that Halevi would be the "defendant" in either context, the distinction is one of great importance to him.

This is also where I lead the class into a discussion about what the law should be as opposed to what it is. We discuss the difference between the Anglo-American common law approach and the civil law approach, and how some states in the US have adopted statutes to create some form of a duty to rescue in some situations. We talk about fairness and how laws

\footnotetext{
${ }^{57}$ If you teach students in a civil law country, you will necessarily need to modify this discussion. If you want to give your students a sense of how a common law country may interpret the statute, however, you may choose to engage in a conversation about the role of cases in a common law system.

In an effort to illustrate the way lawyers and judges use case law to help with statutory interpretation, I sometimes provide my students with an additional handout that contains a number of short synopses of fictional cases that all relate to the same duty to rescue statute. In addition to showing students how case law can help lawyers interpret ambiguous statutory language, the handout also helps introduce the concepts of hierarchy of authority and binding versus persuasive authority.

The prompt on this handout is, "How do the following authorities help you determine whether Halevi violated the statute (assume that all jurisdictions referenced below have a statute with language identical to Washingtonia Code §42.3)?" Two examples of these case synopses are below; for a full copy of the handout please contact the author.
}

Case 1: Washingtonia County Court decision (trial court)

Court held that the scope of employment provision applies only to employment that is relevant to the danger presented. In this case, a lifeguard had a duty to rescue a man drowning in the ocean, even though the circumstances were dangerous.

Case 2: Zoolandia Supreme Court decision (highest appellate court)

Court held that the scope of employment provision applies to any employment that brought the defendant into contact with the distressed individual, whether or not that employment is relevant to the danger presented. In this case, a traveling salesman had a duty to attempt to rescue a woman being stung by a swarm of bees when he encountered the woman at her residence while peddling his wares. 
often don't seem fair or moral or ethical (or they do to some people and not to others). We talk about how what's "legal" may fly in the face of our gut feelings of right and wrong.

These conversations may be as elaborate or as brief as you wish, and will be shaped by the context in which you teach. Classes taking place in common law countries will likely focus on different aspects from those taking place in civil law countries. If your students are graduate students (as all law students are in the US), class discussions may be somewhat more sophisticated than they might be if your students are in their first year of undergraduate studies. If the rest of your syllabus allows, you may even choose to weave the discussion over a series of classes, using the Halevi case as a sort of touchstone to come back to again and again over the course of the semester. This exercise is nothing if not flexible; part of the joy I've found in using it from year to year is that while it dependably serves its role as a mechanism through which to introduce my students to legal analysis, the students' reactions and insights ensure that no two iterations of the exercise are exactly the same.

\section{Conclusion}

Most of the people, they know my picture but there's very few that know about my life ... I'm so thankful that ... I can accept the picture as a powerful gift. Then it is my choice. Then I can work with it for peace. (Kim Phuc, the child depicted in Napalm Girl) ${ }^{58}$

There's quite a bit of power inherent in being a law professor who works with first-semester students as they transition from layperson to legal thinker. We have the power to shape our students' very first experiences of legal education, legal analysis, and legal stories; the impression left by those initial experiences is likely to outlast most of the doctrine and guiding principles we share in the weeks and years hence. While some professors may see cases like Pierson $v$ Post as important rites of passage for students to pass through on the road to becoming

\footnotetext{
58 Supra n. 33.
} 
lawyers, it is hard to overstate the value of contemporary stories like those of Nick Ut, Kevin Carter, R. Umar Abassi, and Marcus Halevi in the law school classroom. Their stories, and the images that accompany them, resonate with students in ways that centuries-old stories lying flat on a casebook page cannot. ${ }^{59}$ Whether or not these photojournalists had or should have had a duty to rescue the people they photographed, they all left behind powerful images whose stories both in front of and behind the lens have changed lives and, indeed, the world. It has been an honor to use these photojournalists' stories in my classroom as I endeavor to inspire each crop of new law students to do the same.

\section{Acknowledgements}

For their helpful comments, conversations, and support, I thank Karen Thornton, Christy DeSanctis, Chloe Wallace, Maureen Collins, Ryan Fletcher, and all the other colleagues, students, and friends who have helped me refine and improve this article and the exercise that inspired it. Thanks also to Ira Glass of This American Life for creating a non-fiction storytelling show that has served as a never-ending source of entertainment and inspiration both in and out of the classroom.

\footnotetext{
${ }^{59}$ It's not uncommon for me to receive emails from former students years after they've graduated law school sharing links to new articles and images implicating "duty to rescue" or new episodes of This American Life that may work well in my first-year classroom.
} 